\title{
Polystyrene nanoparticles activate ion transport in human airway epithelial cells
}

\author{
This article was published in the following Dove Press journal: \\ International Journal of Nanomedicine \\ 27 June 2011 \\ Number of times this article has been viewed
}

\section{J McCarthy' \\ $X$ Gong $^{2}$ \\ D Nahirney ${ }^{2}$ \\ M Duszyk ${ }^{2}$ \\ MW Radomski'}

'School of Pharmacy and Pharmaceutical Sciences, Panoz Institute, Trinity College Dublin, Dublin, Ireland; ' ${ }^{2}$ Department of Physiology, University of Alberta, Edmonton, Alberta, Canada
Correspondence: Joanna McCarthy School of Pharmacy and Pharmaceutical Sciences, Panoz Institute, Trinity College Dublin, Dublin 2, Ireland

Tel +35 3I 8962939

Fax+3531 8963367

Email mccartj7@tcd.ie
Background: Over the last decade, nanotechnology has provided researchers with new nanometer materials, such as nanoparticles, which have the potential to provide new therapies for many lung diseases. In this study, we investigated the acute effects of polystyrene nanoparticles on epithelial ion channel function.

Methods: Human submucosal Calu-3 cells that express cystic fibrosis transmembrane conductance regulator (CFTR) and baby hamster kidney cells engineered to express the wild-type CFTR gene were used to investigate the actions of negatively charged $20 \mathrm{~nm}$ polystyrene nanoparticles on short-circuit current in Calu-3 cells by Ussing chamber and single CFTR $\mathrm{Cl}^{-}$ channels alone and in the presence of known CFTR channel activators by using baby hamster kidney cell patches.

Results: Polystyrene nanoparticles caused sustained, repeatable, and concentration-dependent increases in short-circuit current. In turn, these short-circuit current responses were found to be biphasic in nature, ie, an initial peak followed by a plateau. $\mathrm{EC}_{50}$ values for peak and plateau short-circuit current responses were 1457 and $315.5 \mathrm{ng} / \mathrm{mL}$, respectively. Short-circuit current was inhibited by diphenylamine-2-carboxylate, a CFTR $\mathrm{Cl}^{-}$channel blocker. Polystyrene nanoparticles activated basolateral $\mathrm{K}^{+}$channels and affected $\mathrm{Cl}^{-}$and $\mathrm{HCO}_{3}{ }^{-}$secretion. The mechanism of short-circuit current activation by polystyrene nanoparticles was found to be largely dependent on calcium-dependent and cyclic nucleotide-dependent phosphorylation of $\mathrm{CFTR}^{-}$channels. Recordings from isolated inside-out patches using baby hamster kidney cells confirmed the direct activation of CFTR $\mathrm{Cl}^{-}$channels by the nanoparticles.

Conclusion: This is the first study to identify the activation of ion channels in airway cells after exposure to polystyrene-based nanomaterials. Thus, polystyrene nanoparticles cannot be considered as a simple neutral vehicle for drug delivery for the treatment of lung diseases, due to the fact that they may have the ability to affect epithelial cell function and physiological processes on their own.

Keywords: CFTR, cystic fibrosis transmembrane conductance regulator, ion channels, $\mathrm{K}^{+}$channels, lung cells, polystyrene nanoparticle

\section{Introduction}

Cystic fibrosis is an inheritable disease caused by a mutation in the cystic fibrosis transmembrane conductance regulator (CFTR) gene located on chromosome $7 .{ }^{1}$ The $c f t r$ gene encodes a cAMP-regulated $\mathrm{Cl}^{-}$channel, CFTR, located on the apical membrane of epithelial cells. ${ }^{2}$ Structural analysis of the CFTR protein shows that it consists of a 1480 amino acid backbone containing two nucleotide-binding domains, 12 transmembrane domains, and a unique cytoplasmic regulatory domain. ${ }^{3}$ Phosphorylation of the regulatory domain by cAMP-dependent protein kinase $\mathrm{A}$ is a prerequisite for channel opening. ${ }^{4}$ 
ATP-induced dimerization of nucleotide-binding domains also plays an important role in this process. ${ }^{5}$

There are over 1800 recognized mutations of the $c f t r$ gene which give rise to the disease known as cystic fibrosis. ${ }^{6}$ Lung disease in cystic fibrosis patients is the principal cause of morbidity and mortality associated with the condition, and is characterized by impaired mucus clearance due to altered ion transport by airway epithelial cells. ${ }^{7}$ Submucosal glands of the respiratory system have been proposed as the primary site for the pathology of cystic fibrosis lung disease. ${ }^{8}$ CFTR $\mathrm{Cl}^{-}$channels located on the apical membrane of lung epithelial cells are involved in the regulation of physiological processes, such as cell volume control and transepithelial fluid transport, as well as modulating the function of other ion channels, eg, epithelial $\mathrm{Na}^{+}$channels, outwardly rectifying $\mathrm{Cl}^{-}$channels, and $\mathrm{K}^{+}$channels, and thus the transport of $\mathrm{Na}^{+}, \mathrm{K}^{+}$and $\mathrm{Cl}^{-}$ions, and $\mathrm{H}_{2} \mathrm{O}$. ${ }^{9}$

Nanotechnology is providing science with a new platform in medicine which has the potential to provide disciplines such as diagnostics and clinical medicine, as well as basic research, with new materials in the nanometer range that have many far reaching applications. Nanomaterials, such as nanoparticles, differ from other materials due to a number of special characteristics, including small particle size, large surface area, shape, chemical composition, and charge. ${ }^{10}$ Together these characteristics give nanoparticles numerous advantages over other delivery systems, and the targeted delivery of drugs using nanocarriers for the treatment of respiratory diseases is a major focus of interest. ${ }^{10}$ Many approaches have been undertaken for the delivery of nanostructures, such as micelles, liposomes, and nanoparticles to the lungs via the use of nebulization for suspensions and dry powder carriers. ${ }^{10}$

In 2007, Yacobi et al investigated the effects of ultrafine ambient particulate suspensions, polystyrene nanoparticles, quantum dots, and single-walled carbon nanotubes on transmonolayer resistance $\left(\mathrm{R}_{\mathrm{t}}\right)$ and equivalent short-circuit current on rat alveolar cell epithelia monolayers. They found that $\mathrm{R}_{\mathrm{t}}$ was reduced after apical exposure of rat alveolar cell epithelia monolayers to a variety of nanomaterials, including ultrafine ambient particulate suspensions, positively charged quantum dots, and single-walled carbon nanotubes at varying concentrations. ${ }^{11}$ In turn, other research groups have investigated the interaction of silver nanoparticles on voltage-activated $\mathrm{Na}^{+}$currents in hippocampal CA1 neurons, with results indicating that silver nanoparticles may alter the action potential of these neurons by reducing voltage-gated sodium currents. ${ }^{12}$
Even though there have been many advances in the area of bionanoscience, there is still very little known about the complex interaction of nanoparticles with the cell membrane on airway epithelial cells, and the effect that this interaction can have on many diverse cellular processes. Nanoparticles at the cell membrane have the potential to interact with numerous cell signaling receptors, ion channels, transporters, and cytoskeleton machinery which work to control and regulate basic cellular and physiological processes. Recent studies have shown that gold nanoparticles coated with antibodies have the ability to alter signaling processes and regulate membrane receptor internalization in human breast cancer cells. ${ }^{13}$ Furthermore, titanium dioxide nanoparticles, upon contact with BEAS-2B human bronchial cells, can induce programmed cell death via the mitochondrial apoptosis pathway. ${ }^{14}$

Taken together, our research group was interested in studying the interactions of nanoparticles with ion channels in human airway epithelial cells, with a specific focus on the CFTR $\mathrm{Cl}^{-}$channel. We hypothesized that nanoparticles could modulate epithelial ion channel function. To this end, we wanted to investigate if nanoparticles could affect apically located $\mathrm{CFTR}^{-}$channels and/or other ion channels (basolateral $\mathrm{K}^{+}$channels) and cotransporters, either directly or indirectly. To test this hypothesis, we used commercially available $20 \mathrm{~nm}$ negatively charged polystyrene nanoparticles (N20). We chose to use polystyrene nanoparticles because this specific type of nanoparticle is being increasingly characterized for use in nanosensors and drug nanocarrier investigations. ${ }^{15,16}$ Polystyrene nanoparticles have also been shown to interact with proteins to form a "protein corona" upon interaction with biological fluids, ${ }^{17}$ and more recently studies by Salomon and Ehrhardt have found that polystyrene nanoparticles can affect the function of $\mathrm{P}$ glycoprotein/ MDR1 membrane transporters in A549 human alveolar epithelial cells. ${ }^{18}$

We used the Ussing chamber technique to study the effects of N20 on ion fluxes in human airway submucosal cells, ie, Calu-3. Any findings with the Ussing chamber were then verified with the single channel patch clamp technique using baby hamster kidney cells stably transfected with a wild-type $\mathrm{CFTR}^{-}$channel. We discovered that acute apical exposure of lung epithelial cells to N20 promoted transepithelial ion transport, affecting not only apically located CFTR $\mathrm{Cl}^{-}$channels but also basolateral $\mathrm{K}^{+}$channels. The mechanism of short-circuit current activation by nanoparticles was found to be mainly dependent on calcium-dependent and cyclic nucleotide-dependent phosphorylation of $\mathrm{CFTR}^{-}$channels. 
Our patch clamp data reveal an exciting new phenomenon that nanoparticles can interact and activate $\mathrm{CFTR}^{-}$channels directly. No other study to our knowledge has shown the direct activation of airway ion channels by polystyrene nanoparticles.

\section{Materials and methods Chemicals}

Polystyrene latex beads were purchased from Invitrogen (carboxyl-modified 20 nm, F-8787; Carlsbad, CA) and corelabeled with fluorophore according to the manufacturer's specifications. Before all experiments, test solutions of polystyrene nanoparticles were dispersed using a sonicator (8890-MTH; Cole-Parmer, Vernon Hills, IL) to prevent aggregation. Forskolin (10 mM; LC Laboratories, Woburn, MA) was made as a 1000-fold stock solution in ethanol. Diphenylamine-2-carboxylate $1 \mathrm{M}$ was dissolved in dimethyl sulfoxide and was prepared fresh for each experiment. Furosemide $100 \mathrm{mM}$ was sourced from Sigma-Aldrich (St Louis, MO) and was dissolved in distilled $\mathrm{H}_{2} \mathrm{O}$ with one drop of concentrated $\mathrm{NaOH} 5$ N. XE991 (10 mM) was a generous gift from Dr BS Brown (DuPont, Wilmington, DE) and was dissolved in $\mathrm{HCl} 0.1 \mathrm{~N}$. Nystatin was prepared as a $180 \mathrm{mg} / \mathrm{mL}$ stock solution in dimethyl sulfoxide and sonicated for 30 seconds just before use. Clotrimazole $30 \mathrm{~mL}$ was sourced from Sigma-Aldrich and was made as a 1000-fold stock solution in ethanol. Carbachol $100 \mathrm{mM}$ and $S$-nitrosoglutathione $100 \mathrm{mM}$ were purchased from Sigma-Aldrich and dissolved in distilled $\mathrm{H}_{2} \mathrm{O}$. NG-nitro- ${ }_{\mathrm{L}}$-arginine methyl ester ${ }_{\mathrm{L}}$-NAME) $100 \mathrm{mM}$ was purchased from Alexis Biochemicals (San Diego, CA). 1H-[1, 2, 4] oxadiazolol-[4, 3- $a$ ] quinoxalin-1-one (ODQ, 10 mM; Tocris Cookson, St Louis, MO) and thapsigargin $1 \mathrm{mM}$ (Sigma-Aldrich) were prepared as 1000-fold stock solutions in dimethyl sulfoxide. All other items were purchased from Sigma-Aldrich.

\section{Cell lines and culture}

A Calu-3 cell line was obtained from the American Type Culture Collection (ATCC HBT-55) and maintained as a monolayer culture in plastic $\mathrm{T}-75 \mathrm{~cm}^{2}$ tissue culture flasks. The cells were grown in Dulbecco's Modified Eagle's Medium, a low glucose media $1 \mathrm{~g} / \mathrm{L}$ also containing sodium pyruvate $110 \mathrm{mg} / \mathrm{L}$ and supplemented with $10 \%$ fetal bovine serum, gentamicin sulfate $5 \mu \mathrm{g} / \mathrm{mL}$, penicillin $\mathrm{G} 6 \mu \mathrm{g} / \mathrm{mL}$, and streptomycin $10 \mu \mathrm{g} / \mathrm{mL}$. Cells were maintained at $37^{\circ} \mathrm{C}$ in a humidified atmosphere of $95 \% \mathrm{O}_{2}$ and $5 \% \mathrm{CO}_{2}$. When confluent, the cell line was detached enzymatically with trypsin-ethylenediamine tetra-acetic acid and subcultured into a new cell culture flask. The medium was replaced every 2 days. Cells were used for experiments between passages 21-45. For transepithelial measurements, Calu-3 cells were seeded at a density of $2 \times 10^{5}$ cells $/ \mathrm{cm}^{2}$ onto Snapwell ${ }^{\mathrm{TM}}$ inserts $\left(0.45 \mu \mathrm{m}, 1 \mathrm{~cm}^{2}\right.$; Corning, Cambridge, MA). For the first 7 days, cells were grown in liquid-covered culture, with the basolateral and apical media being changed every 2 days ( $2 \mathrm{~mL}$ media basolaterally, $500 \mu \mathrm{L}$ apically). After day 7 , from initial seeding on Snapwell inserts, all cells were grown using air interface culturing in which medium was added only to the basolateral side of the inserts $(2 \mathrm{~mL})$. Cells were used in transepithelial experiments on days 12-22.

\section{Size and zeta potential determination for polystyrene nanoparticles}

The size and zeta potential for N20 was determined using a Zetasizer Nano ZS (Malvern Instruments, Worcestershire, UK). Zeta potential and size was measured at $37^{\circ} \mathrm{C}$, three repeats per sample. Polystyrene nanoparticles were diluted in Krebs-Henseleit solution containing (in $\mathrm{mM}$ ): $\mathrm{NaCl}, 116.4$; $\mathrm{KCl}, 4.7 ; \mathrm{CaCl}_{2}, 1.8 ; \mathrm{MgCl}_{2}, 1.2 ; \mathrm{NaH}_{2} \mathrm{PO}_{4}, 0.78 ; \mathrm{NaHCO}_{3}$, 25.0; and 10 glucose ( $\mathrm{pH}$ was $7.4 \pm 0.1$ when bubbled with $95 \% \mathrm{O}_{2}$ and $5 \% \mathrm{CO}_{2}$ ). Measurements were conducted using a concentration of $100 \mu \mathrm{g} / \mathrm{mL}$. The dielectric constant of the dispersant was set at 78.5 , viscosity as for water at $0.8872 \mathrm{cP}$, and refractive index at 1.333 .

\section{Cytotoxicity}

Lactate dehydrogenase assay and polystyrene nanoparticles

To evaluate the cytotoxicity of N20 alone on Calu-3 cells, $10^{4} \times$ cells $/ 100 \mu \mathrm{L}$ of cell culture medium were plated into 96-well round-bottom plates, and the lactate dehydrogenase assay was performed. Extracellular lactate dehydrogenase release was measured using a colorimetric CytoTox $96^{\circledR}$ nonradioactive cytotoxicity assay kit from Promega (Madison, WI) following the manufacturer's instructions, with absorbance recorded at $492 \mathrm{~nm}$ (FLUOstar, OPTIMA; BMG Labtech, Offenburg, Germany). N20 was diluted in serum-free medium and was added to cells (in triplicate) at concentrations of 1, 10, 25, 50, 100, and $200 \mu \mathrm{g} / \mathrm{mL}$. Cell survival was determined 24 hours posttreatment with $\mathrm{N} 20$ by the lactate dehydrogenase assay described above. To determine the percentage cytotoxicity, the average absorbance of the triplicate was calculated. As control, extracellular release of lactate dehydrogenase was obtained from unexposed cells (low control), and maximum release of lactate dehydrogenase was obtained by lysis of cells 
with the supplied lysis buffer (high control). The following equation was applied to the experimental values obtained: percent cytotoxicity $=$ release of lactate dehydrogenase from exposed cells - release of lactate dehydrogenase (low control)/release of lactate dehydrogenase (high control) - release of lactate dehydrogenase (low control) $\times 100$.

\section{MTT assay and polystyrene nanoparticles}

Cytotoxicity was measured using a CellTiter $96^{\circledR}$ nonradioactive cell proliferation assay kit from Promega following the manufacturer's instructions. Calu-3 cells were seeded in triplicate at a density of $10^{4} \times$ cells $/ 100 \mu \mathrm{L}$ of cell culture medium into 96 -well plates. The following day, Calu-3 cells were treated with N20 under serum-free conditions at the following concentrations; 1, 10, 25, 50, 100, and $200 \mu \mathrm{g} / \mathrm{mL}$ for 24 hours. The 3-(4,5-dimethyl-thiazol-2-yl)2,5-diphenyltetrazolium bromide (MTT) assay evaluates mitochondrial activity (cell growth and cell death) and is performed by adding a premixed optimized dye solution to culture wells. Absorbance is recorded at $570 \mathrm{~nm}$ (FLUOstar). The recorded absorbance is directly proportional to the number of live cells. To determine the percentage cytotoxicity, the average of the triplicates was calculated for each concentration tested. Results were calculated as a percentage of the control values (unexposed cells), where percent cytotoxicity $=\left(\right.$ experimental abs $_{570 \mathrm{~nm}}$ of exposed cells $/ \mathrm{abs}_{570 \mathrm{~nm}}$ of unexposed cells) $\times 100$.

\section{Transepithelial measurements}

Ussing chamber studies were carried out using the apparatus and methods described by Duta et al ${ }^{19}$ and Duszyk. ${ }^{20}$ Prior to use in transepithelial measurement studies, all Calu-3 cell inserts were fed with complete fresh media for 1 hour and were washed for 30 minutes in Krebs-Henseleit solution ( $2 \mathrm{~mL}$ basolaterally, $500 \mu \mathrm{L}$ apically). Calu-3 cell monolayers were grown on Snapwell inserts for at least 12 days prior to mounting into modified Ussing chambers. The cell monolayers were bathed at a temperature of $37^{\circ} \mathrm{C}$ in KrebsHenseleit solution. Chemicals were added from concentrated stocks and all chambers were continuously mixed by bubbling the Krebs-Henseleit solution with $95 \% \mathrm{O}_{2}$ and $5 \% \mathrm{CO}_{2}$ to maintain a constant $\mathrm{pH}$ of 7.4. The transepithelial potential difference was clamped to zero using a DVC 1000 voltage/ current amplifier (World Precision Instruments, Sarasota, FL), and the resulting short-circuit current was recorded by $\mathrm{Ag}-\mathrm{AgCl}_{2}$ electrodes, using $3 \mathrm{M} \mathrm{KCl}$ agar bridges. The short-circuit current was allowed to stabilize for up to approximately 10 minutes or more before the application of nanoparticles or other tested chemicals. Nanoparticles were always added apically. The transepithelial resistance was calculated using Ohm's law, by measuring current changes in response to $0.5 \mathrm{mV}$ pulses.

\section{Basolateral membrane $\mathrm{K}^{+}$currents}

The effects of the nanoparticles on basolateral membrane $\mathrm{K}^{+}$ channels were measured after permeabilization of the apical membrane with nystatin $180 \mu \mathrm{g} / \mathrm{mL}$ and establishment of an apical-to-basolateral $\mathrm{K}^{+}$concentration gradient. Apical $\mathrm{NaCl}$ was replaced by equimolar amounts of potassium gluconate and basolateral $\mathrm{NaCl}$ with sodium gluconate. The concentration of calcium gluconate was increased from $2.5 \mathrm{mM}$ to $5 \mathrm{mM}$. Under such conditions, the contribution of apical $\mathrm{Cl}^{-}$channels to the short-circuit current is eliminated and the measured short-circuit current represents $\mathrm{K}^{+}$currents as these ions move down the concentration gradient through basolateral $\mathrm{K}^{+}$channels.

\section{Anion substitution studies $\mathrm{HCO}_{3}^{-}$free transepithelial measurements and polystyrene nanoparticles}

The effects of nanoparticles on the short-circuit current were assessed in the absence of bicarbonate ions. A bicarbonatefree Krebs-Henseleit solution was used with apical and basolateral $\mathrm{HCO}_{3}^{-}$ions exchanged for HEPES $10 \mathrm{mM}$. The overall $\mathrm{pH}$ was adjusted to 7.4 and the solutions were mixed with $\mathrm{O}_{2}$.

\section{Low $\mathrm{Cl}^{-}$transepithelial measurement and} polystyrene nanoparticles

The effects of nanoparticles on the short-circuit current were measured under low chloride conditions. A low chloride Krebs-Henseleit solution was used with apical and basolateral $\mathrm{NaCl}$ being exchanged for sodium gluconate $116 \mathrm{mM}$ and $\mathrm{KCl}$ for potassium gluconate $4.7 \mathrm{mM}$. The concentration of calcium gluconate was increased to $5 \mathrm{mM}$ to compensate for the $\mathrm{Ca}^{2+}$-buffering capacity of the gluconate.

\section{Patch clamp experiments}

These experiments were carried out using baby hamster kidney cells stably transfected with wild-type human CFTR, as previously described. ${ }^{21}$ The experiments were performed in the excised, inside-out configuration of the patch clamp technique. In all experiments, the pipette solution contained (in $\mathrm{mM}$ ) sodium gluconate $150, \mathrm{MgCl}_{2} 2$, and HEPES 10 , and the bath solution $\mathrm{NaCl} 150, \mathrm{MgCl}_{2} 2$, and HEPES 10 . All solutions were adjusted to $\mathrm{pH} 7.4$ with $\mathrm{NaOH} 5 \mathrm{~N}$. 
The membrane potential was held at $0 \mathrm{mV}$ and the junction potential was compensated. Following patch excision, channel activity was assessed by the addition of N20 $50 \mu \mathrm{g} / \mathrm{mL}$ to the bath solution. Controls (untransfected baby hamster kidney cell patches) were treated with N20 $50 \mu \mathrm{g} / \mathrm{mL}$, as described earlier. This concentration was chosen based on Ussing chamber studies showing that $\mathrm{N} 2050 \mu \mathrm{g} / \mathrm{mL}$ resulted in maximal stimulation of transepithelial anion fluxes. In the second set of experiments, the patch excision was exposed to N20, as already discussed, in the presence of a 10-20 nM protein kinase as a catalytic subunit and MgATP 0.2 to $1 \mathrm{mM}$ in the bath. $\mathrm{Au}(\mathrm{CN})_{2} 500 \mu \mathrm{M}$ was used as a blocker of the CFTR channel. Patch clamp recordings were analyzed by the Clampfit program, and open probability $\left(\mathrm{P}_{\mathrm{o}}\right)$ was calculated using standard techniques.

\section{Data analysis}

Nanoparticle concentration-response was fitted with the following equation:

$$
\begin{aligned}
\mathrm{Y}= & \text { bottom }+(\text { top-bottom }) /\left(1+10^{\wedge}[(\operatorname{LogEC} 50-\mathrm{X})\right. \\
& \times \text { Hill Slope }])
\end{aligned}
$$

The data points show the mean \pm the standard error of the mean. The short-circuit current is expressed in units of $\mu \mathrm{A} / \mathrm{cm}^{2}$. All data are presented as group means \pm standard error of the mean for the individual experiments. Statistical analysis of the mean difference between multiple groups was determined by one-way analysis of variance, followed by Bonferroni post hoc tests or between two groups by paired/ unpaired $t$-tests as appropriate. A $P$ value of $<0.05$ was considered statistically significant. All statistical analyses were performed using GraphPad Prism (v 5.00 for Windows; GraphPad Software, San Diego, CA).

\section{Results}

\section{Nanoparticle characterization}

N20 nanoparticles according to manufacturer's specifications were $20 \mathrm{~nm}$ in size and negatively charged. Our own measurements have shown that $\mathrm{N} 20$ had a $\mathrm{Z}$ average $(\mathrm{nm})$ of $45.2 \pm 0.01$, a zeta potential of $-15.1 \pm 0.8 \mathrm{mV}$, and a polydispersity index of $0.22 \pm 0.002$ in Krebs-Henseleit solution. Furthermore, our lactate dehydrogenase cytotoxicity studies showed that N20 1-200 $\mu \mathrm{g} / \mathrm{mL}$ did not exert any cytotoxic effects on Calu-3 cells for up to 24 hours ( $n=4$, data not shown). Also, we did not observe any significant changes in Calu-3 cell viability by MTT analysis after cells were exposed to N20 1-200 $\mu \mathrm{g} / \mathrm{mL}$ over a 24-hour period (cell viability at the highest concentration of N20 tested was $92.5 \% \pm 5.7 \%$ vs control, $P>0.05, \mathrm{n}=3)$.

\section{Nanoparticles activate anion secretion in Calu-3 cells}

Acute apical exposure of Calu-3 cells to N20 activated the short-circuit current in a concentration-dependent manner. Figure 1 shows the fitting of equation (1) to the experimental data. The current activated by N20 showed a biphasic response, ie, an initial peak followed by a plateau. Both peak and plateau values were used to determine the $\mathrm{EC}_{50}$ and Hill coefficient (Figures 1A and 1B,) with both values working at low concentrations $(1457 \mathrm{ng} / \mathrm{mL}$ for peak short-circuit current and $315.5 \mathrm{ng} / \mathrm{mL}$ for plateau short-circuit current, respectively). Therefore, in our remaining anion transport studies, plateau and peak short-circuit current values are reported where appropriate to determine the effect of N20 on the short-circuit current.

Apically located $\mathrm{CFTR}^{-}$channels serve as the primary conductive pathway for anion secretion in Calu-3 cells and are the main contributors to the short-circuit current in transepithelial studies. To determine the mechanism(s) of action of nanoparticles on short-circuit current activation, a number of pharmacological agents were used to probe the actions of nanoparticles on ion channels. N20 $10 \mu \mathrm{g} / \mathrm{mL}$ increased short-circuit current by $12.4 \pm 0.4 \mu \mathrm{A} / \mathrm{cm}^{2}$ (plateau $\mathrm{I}_{\mathrm{sc}}$, Figure 2A). The subsequent addition of forskolin, an activator of adenylyl cyclase $(10 \mu \mathrm{M})$, further increased the short-circuit current by $15.8 \pm 2.9 \mu \mathrm{A} / \mathrm{cm}^{2}$ (plateau $\mathrm{I}_{\mathrm{sc}}$, Figure 2A) and this effect was blocked by diphenylamine-2carboxylate, a blocker of CFTR $(1 \mathrm{mM}){ }^{22}$ In the absence of nanoparticles, forskolin activated the short-circuit current by $16.2 \pm 1.0 \mu \mathrm{A} / \mathrm{cm}^{2}$ (plateau $\mathrm{I}_{\mathrm{sc}}$, Figure 2B). However, the subsequent addition of $\mathrm{N} 20$ after forskolin resulted in a significantly lower short-circuit current response $\left(4.7 \pm 2.4 \mu \mathrm{A} / \mathrm{cm}^{2}\right)$ when compared with control responses $(P<0.05, \mathrm{n}=3$, Figure 2B), showing that there is in fact an overlap between the mechanism of short-circuit current activation by N20 and forskolin. A summary of the statistical analysis of Figures $2 \mathrm{~A}$ and $2 \mathrm{~B}$ is shown in Figure 2D.

As shown on Figure 2C, diphenylamine-2-carboxylate $1 \mathrm{mM}$ reduced the basal short-circuit current by $9.2 \pm 1.6 \mu \mathrm{A} / \mathrm{cm}^{2}$ prior to the addition of $\mathrm{N} 2010 \mu \mathrm{g} / \mathrm{mL}$. However, this pretreatment with diphenylamine-2-carboxylate only partially inhibited the activation of short-circuit current by $\mathrm{N} 20\left(5.0 \pm 2.3 \mu \mathrm{A} / \mathrm{cm}^{2}\right)$ when compared with control responses of $28.72 \pm 3.5 \mu \mathrm{A} / \mathrm{cm}^{2}\left(\right.$ peak $_{\mathrm{sc}}, P<0.05$, 

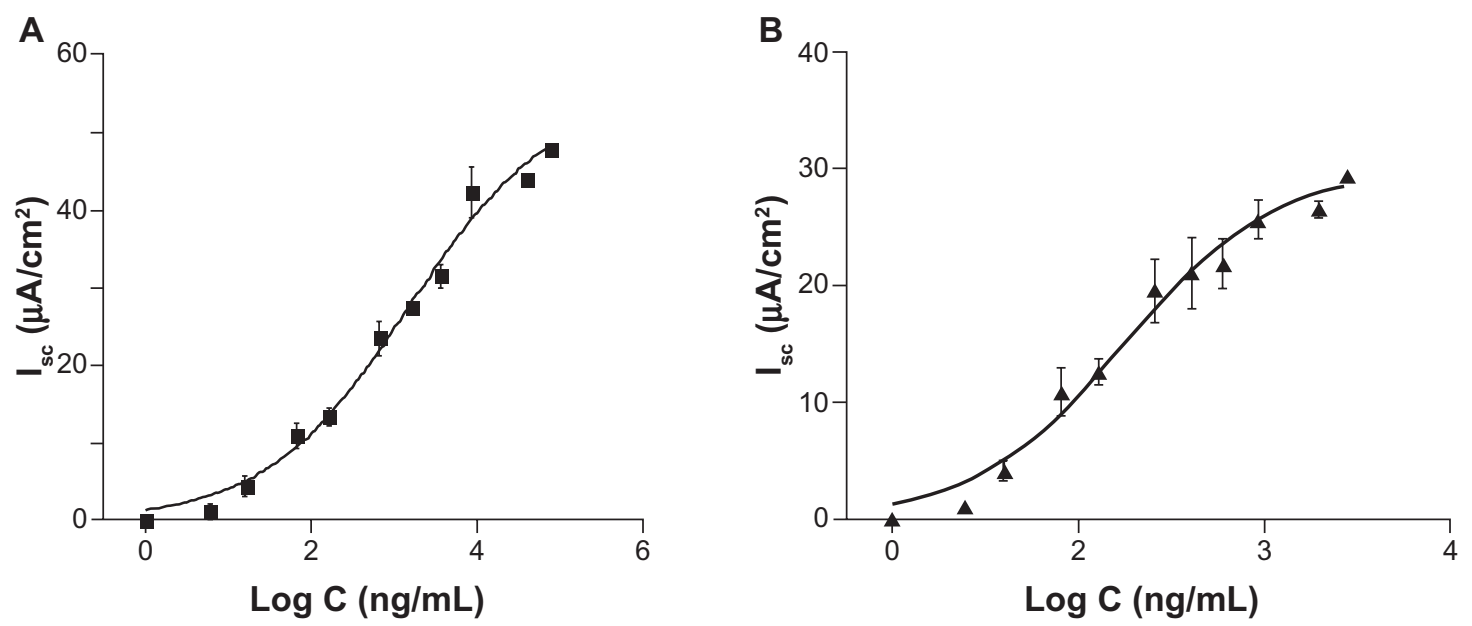

Figure I Concentration-response curves for short-circuit current activation by N20 in Calu-3 cells. A) Peak EC $50=1457 \mathrm{ng} / \mathrm{mL}$ and a Hill coefficient of $0.52 \pm 0.035$ ( $\mathrm{n}=4$ ). B) Plateau $\mathrm{EC}_{50}=315.5 \mathrm{ng} / \mathrm{mL}$ and a Hill coefficient of $0.54 \pm 0.045(\mathrm{n}=4)$.

unpaired $t$-test, $\mathrm{n}=3$, Figure 2C). Furosemide, a blocker of the NKCC cotransporter located on the basolateral membrane, exerted little effect on inhibition of the short-circuit current caused by N20 in the presence of diphenylamine-2carboxylate (Figure 2C).

\section{Nanoparticles activate $\mathrm{K}^{+}$channels in Calu-3 cells}

Observations made in previous experiments (Figure 2C) which showed that N20 was capable of increasing the short-circuit current in the presence of a blocked CFTR and also that furosemide had minimal effect on the blocking of short-circuit current in the presence of diphenylamine-2carboxylate, suggested that N20 in addition to CFTR has other ion channel and/or cotransporter targets. Thus, we began to investigate the interactions between basolateral $\mathrm{K}^{+}$channels and nanoparticles, because these channels can also act as a driving force for anion secretion in Calu-3 cells.

Nystatin was used to permeabilize the apical membrane in the presence of an established transepithelial ion gradient to measure $\mathrm{K}^{+}$currents. In our experiments, permeabilization of the apical membrane with nystatin $180 \mu \mathrm{g} / \mathrm{mL}$ led to an increase in the short-circuit current of $97.3 \pm 13.4 \mu \mathrm{A} / \mathrm{cm}^{2}$. N20 $10 \mu \mathrm{g} / \mathrm{mL}$ apical, activated $\mathrm{K}^{+}$current in Calu-3 cells by a further $56.2 \pm 6.7 \mu \mathrm{A} / \mathrm{cm}^{2}$ (Figure 3A). The activation of $\mathrm{K}^{+}$currents by N20 was inhibited by XE991, a potent and selective inhibitor of $\mathrm{K}^{+}$channels, ${ }^{23}$ with an average reduction in the short-circuit current of $57.6 \pm 9.0 \mu \mathrm{A} / \mathrm{cm}^{2}$.

To investigate if this effect of nanoparticles on $\mathrm{K}^{+}$channels was cAMP-dependent, Calu-3 cells were pretreated with forskolin $10 \mu \mathrm{M}$ both sides. Forskolin increased the short-circuit current by $39.3 \pm 9.2 \mu \mathrm{A} / \mathrm{cm}^{2}$ and abolished the effects of $\mathrm{N} 2010 \mu \mathrm{g} / \mathrm{mL}$ on $\mathrm{K}^{+}$currents (Figure 3B). Moreover, forskolin-induced activation of $\mathrm{K}^{+}$channels was XE991-sensitive, decreasing the shortcircuit current by $114.2 \pm 17.6 \mu \mathrm{A} / \mathrm{cm}^{2}$, thus again showing that $\mathrm{N} 20$ activates $\mathrm{K}^{+}$currents in a cAMP-dependent manner (Figure 3B). Further confirmation that N20 acts through the cAMP-pathway came from data showing that N20-activated $\mathrm{K}^{+}$currents in Calu-3 cells were not sensitive to clotrimazole, a known inhibitor of $\mathrm{Ca}^{2+}$-regulated $\mathrm{K}^{+}$channels (Figure 3C).

\section{Anion substitution studies}

In airway epithelial cells such as Calu-3, the primary basolateral entry pathways for $\mathrm{Cl}^{-}$and $\mathrm{HCO}_{3}{ }^{-}$anions are through the $\mathrm{NKCC}$ and $\mathrm{Na}^{+}-\mathrm{HCO}_{3}^{-}$cotransporters, respectively. Both anions have been shown to leave the cell via CFTR $\mathrm{Cl}^{-}$channels. We wanted to examine if either one of these two anions $\left(\mathrm{Cl}^{-}\right.$or $\left.\mathrm{HCO}_{3}^{-}\right)$is preferentially secreted by Calu-3 cells upon stimulation by N20. In these experiments, we decided to use forskolin short-circuit current responses as a point for comparison with N20-induced short-circuit current responses.

When we compared the responses of forskolin and N20 on the short-circuit current in normal Krebs-Henseleit solution, we found no significant differences between their stimulation of short-circuit current; $36.3 \pm 1.5$ vs $29.8 \pm 4.8 \mu \mathrm{A} /$ $\mathrm{cm}^{2}$, respectively (peak $\mathrm{I}_{\mathrm{sc}}, P>0.05, \mathrm{n}=3$ ). However, when we compared the response of $\mathrm{N} 20\left(11.7 \pm 2.0 \mu \mathrm{A} / \mathrm{cm}^{2}\right)$ on short-circuit current under conditions free of $\mathrm{HCO}_{3}^{-}$with that 
A

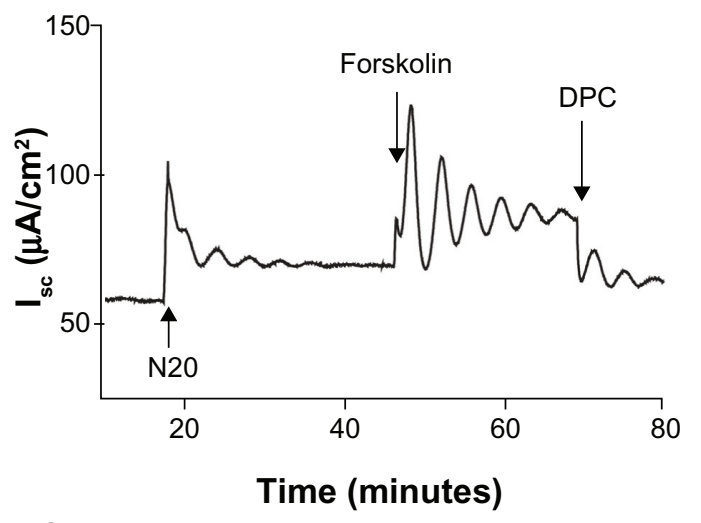

C

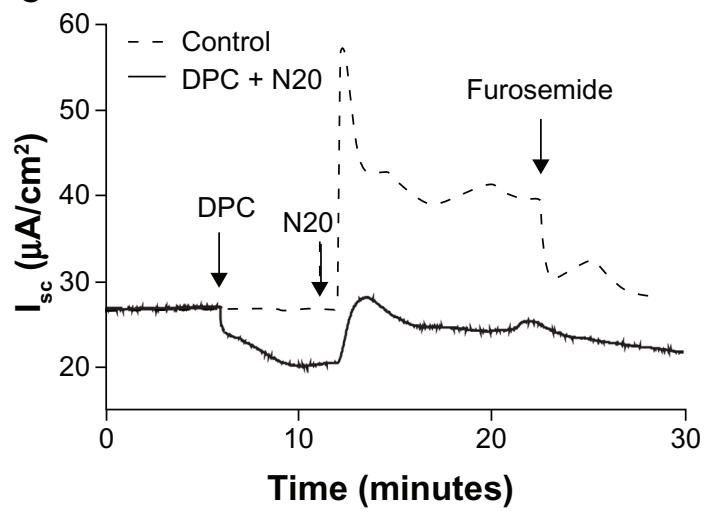

B

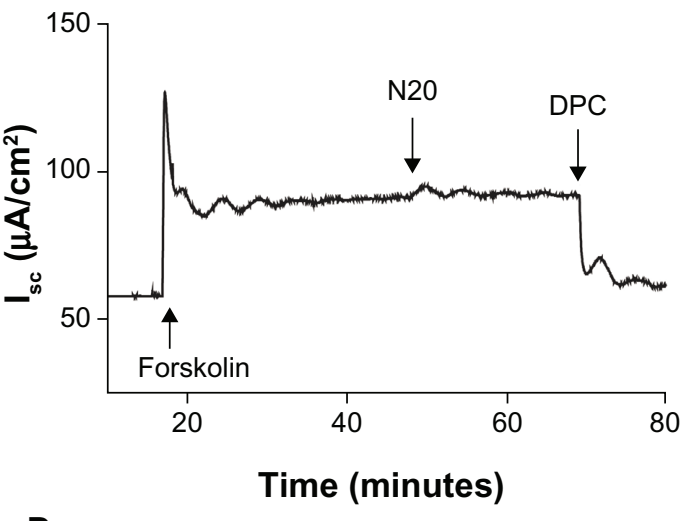

D

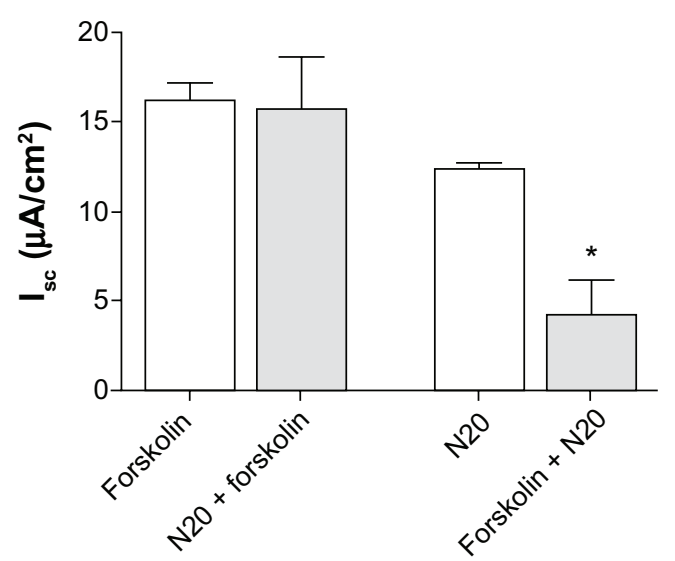

Figure 2 The effect of N20 on transepithelial anion secretion in Calu-3 cells. A) Activation of the short-circuit current by N20 I0 $\mu$ g/mL apical. Forskolin I0 $\mu$ M both sides further increased short-circuit current in N20 pretreated cells. B) Activation of the short-circuit current by N20 was significantly reduced when cells had been prestimulated with forskolin. C) Pretreatment of cells with diphenylamine-2-carboxylate I mM apical reduced the effects of N20. Furosemide I mM basolaterally inhibited the effect of N20 on the short-circuit current. D) Statistical analysis of the effects of N20 on the short-circuit current in the presence and absence of forskolin.

Note: $* P<0.05(n=3$, one-way analysis of variance).

of forskolin $\left(35.7 \pm 8.8 \mu \mathrm{A} / \mathrm{cm}^{2}\right)$ under the same conditions, we found a significant decrease in N20-induced short-circuit current responses (peak $\mathrm{I}_{\mathrm{sc}}, P<0.05, \mathrm{n}=4$ ). Similarly, we observed a reduction in $\mathrm{N} 20$-induced short-circuit current responses under low $\mathrm{Cl}^{-}$conditions $\left(26.1 \pm 3.5 \mu \mathrm{A} / \mathrm{cm}^{2}\right)$ when compared with forskolin $\left(58.8 \pm 0.7 \mu \mathrm{A} / \mathrm{cm}^{2}\right.$, peak $\mathrm{I}_{\mathrm{sc}}, P<0.05$, $n=4)$. A summary of these results is shown in Figure 4 . In all experiments, the addition of diphenylamine-2-carboxylate $1 \mathrm{mM}$ apical reduced the activated short-circuit current to baseline levels (data not shown).

For each set of experiments carried out using either normal $\mathrm{KH}, \mathrm{HCO}_{3}^{-}$free, or low $\mathrm{Cl}^{-}$solutions, the ratio for the N20-activated short-circuit current as a factor of the forskolin-activated short-circuit current was calculated (N20induced short-circuit current/forskolin induced short-circuit current). The ratio value under normal Krebs-Henseleit solution conditions was found to be $0.82 \pm 0.1$. The ratio value we obtained under $\mathrm{HCO}_{3}{ }^{-}$free and low $\mathrm{Cl}^{-}$conditions was $0.32 \pm 0.06$ and $0.42 \pm 0.08$, respectively. Therefore, $\mathrm{N} 20$-induced short-circuit current responses are dependent on both $\mathrm{HCO}_{3}^{-}$and $\mathrm{Cl}^{-}$transport by airway cells.

\section{Nanoparticles affect $\mathrm{Ca}^{2+}$-mediated anion secretion in Calu-3 cells}

In these studies, we used carbachol and thapsigargin (an endoplasmic reticulum $\mathrm{Ca}^{2+}$-ATPase inhibitor), both known agonists of $\mathrm{Ca}^{2+}$-dependent signaling, to probe the actions of nanoparticles on $\mathrm{Ca}^{2+}$-mediated short-circuit current responses in Calu-3 cells. Carbachol, a cholinergic agonist which causes the release of $\mathrm{Ca}^{2+}$ ions from intracellular stores (100 $\mu \mathrm{M}$ basolateral), increased short-circuit current by $12.4 \pm 0.6 \mu \mathrm{A} / \mathrm{cm}^{2}$ (peak $\mathrm{I}_{\mathrm{sc}}$, data not shown). The subsequent addition of $\mathrm{N} 2010 \mu \mathrm{g} / \mathrm{mL}$ apical further increased the short-circuit current by $57.3 \pm 1.8 \mu \mathrm{A} / \mathrm{cm}^{2}$ (peak $\mathrm{I}_{\mathrm{sc}}$ ), and this effect was blocked by $\mathrm{BaCl}_{2} 5 \mathrm{mM}$, basolateral a blocker of $\mathrm{K}^{+}$channels, by $30.8 \pm 1.0 \mu \mathrm{A} / \mathrm{cm}^{2}$ (data not shown). 

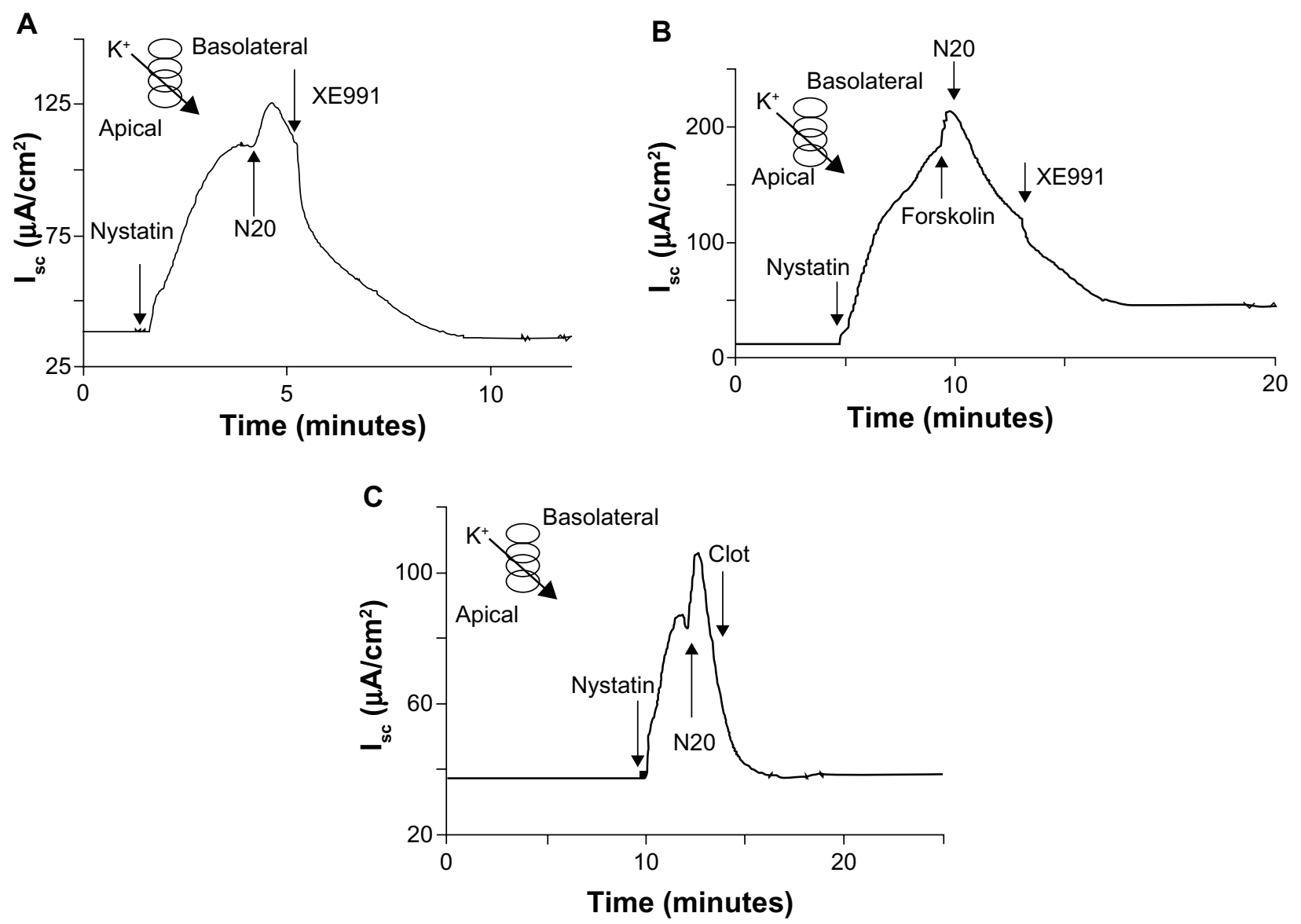

Figure 3 The effects of $\mathrm{N} 20$ on basolateral membrane $\mathrm{K}^{+}$currents. A) $\mathrm{N} 2010 \mu \mathrm{g} / \mathrm{mL}$ apical activated $\mathrm{K}^{+}$currents. The effect of $\mathrm{N} 20$ was inhibited by XE99I $10 \mu \mathrm{M}$ basolateral. B) Prestimulation of cell monolayers with forskolin $10 \mu \mathrm{M}$ both sides abolished the effects of $\mathrm{N}_{20}$ on $\mathrm{K}^{+}$currents; effect of forskolin was inhibited by $\mathrm{XE99I.}$ C) Clotrimazole $30 \mu \mathrm{M}$ basolateral did not block the effects of $\mathrm{N} 20$ on $\mathrm{K}^{+}$currents.

On the other hand, in the absence of carbachol, N20 activated the short-circuit current by $37.9 \pm 5.8 \mu \mathrm{A} / \mathrm{cm}^{2}$ (peak $\mathrm{I}_{\mathrm{sc}}$, Figure 5A). Furthermore, the addition of carbachol after N20 significantly increased the short-circuit current by $123 \pm 22.6 \mu \mathrm{A} / \mathrm{cm}^{2}$ (peak I $_{\text {sc }}$, Figure 5A). As expected, $\mathrm{BaCl}_{2} 5 \mathrm{mM}$, basolateral reduced the short-circuit current by $29.7 \pm 3.8 \mu \mathrm{A} / \mathrm{cm}^{2}$ (Figure $5 \mathrm{~A}$ ). A summary of the statistical analysis is shown in Figure $5 \mathrm{~B}$.

To elucidate further the mechanisms by which N20 synergistically increased short-circuit current responses in the presence of carbachol, we used thapsigargin to investigate if N20 was affecting $\mathrm{Ca}^{2+}$-dependent cell signaling directly via the involvement of intracellular $\mathrm{Ca}^{2+}$ stores. Thapsigargin $1 \mu \mathrm{M}$ bilaterally was found to increase the short-circuit current by $16.5 \pm 3.6 \mu \mathrm{A} / \mathrm{cm}^{2}$ in Calu-3 cells (peak $\mathrm{I}_{\mathrm{sc}}$, Figure $5 \mathrm{C}$ ). The subsequent addition of $\mathrm{N} 2010 \mu \mathrm{g} / \mathrm{mL}$ apical further increased the short-circuit current by $53.5 \pm 5.2 \mu \mathrm{A} / \mathrm{cm}^{2}$ (peak $\mathrm{I}_{\mathrm{sc}}$, Figure 5C) and this effect was blocked by furosemide $1 \mathrm{mM}$ basolateral, decreasing the stimulated shortcircuit current by $44.5 \pm 4.8 \mu \mathrm{A} / \mathrm{cm}^{2}$, and $\mathrm{BaCl}_{2} 5 \mathrm{mM}$ basolateral transiently reduced the short-circuit current by a further $13.3 \pm 0.5 \mu \mathrm{A} / \mathrm{cm}^{2}$. In the absence of thapsigargin, N20 activated the short-circuit current by $49.4 \pm 3.4 \mu \mathrm{A} / \mathrm{cm}^{2}$ (peak $\mathrm{I}_{\mathrm{sc}}$, Figure 5D). Furthermore, the addition of thapsigargin after N20 increased the short-circuit current by $65.8 \pm 3.6 \mu \mathrm{A} / \mathrm{cm}^{2}$ (peak $\mathrm{I}_{\mathrm{sc}}$, Figure 5D). Furosemide $1 \mathrm{mM}$ basolateral and $\mathrm{BaCl}_{2} 5 \mathrm{mM}$ basolateral both reduced the short-circuit current by $49.4 \pm 11.4$ and $10.5 \pm 0.1 \mu \mathrm{A} / \mathrm{cm}^{2}$, respectively (Figure D). The statistical analysis of results in Figures 5C-5D is shown in Figure 5E. Overall, these results indicate that $\mathrm{N} 20$ can act upon $\mathrm{Ca}^{2+}$-dependent cell signaling to drive anion secretion, and that intracellular calcium stores may be the source of this cation in Calu-3 cells.

\section{Nanoparticles affect soluble guanylyl cyclase-cGMP cell signaling involved in anion secretion}

The nitric oxide-soluble guanylyl cyclase-cGMP pathway is an important pathway for anion secretion in respiratory cells. ${ }^{20,24}$ Therefore, we wanted to investigate the effect 


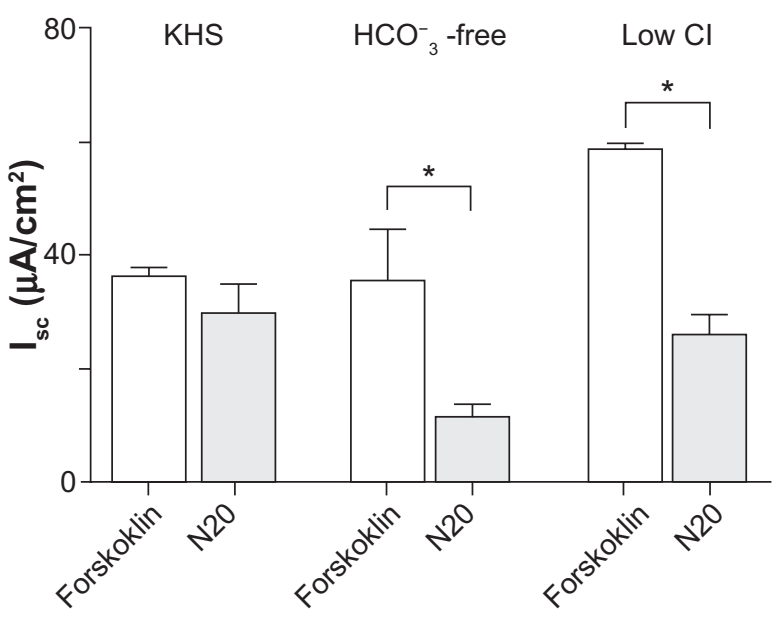

Figure 4 Effects of anion substitution on forskolin and N20 short-circuit current responses. A summary of the effects of anion substitution on forskolin and N20 short-circuit current responses in Calu-3 cell monolayers.

Note: $* p<0.05$ ( $n=4$, one-way analysis of variance).

of N20 on the short-circuit current in the presence and absence of the nitric oxide donor, S-nitrosoglutathione. In the absence of S-nitrosoglutathione, N20 $10 \mu \mathrm{g} / \mathrm{mL}$ apical activated the short-circuit current by $11.8 \pm 3.3 \mu \mathrm{A} / \mathrm{cm}^{2}$ (peak $\mathrm{I}_{\mathrm{sc}}$ ). In the presence of S-nitrosoglutathione $100 \mu \mathrm{M}$ both sides, N20 increased the short-circuit current by only $2.4 \pm 0.7 \mu \mathrm{A} / \mathrm{cm}^{2}$ (peak $\mathrm{I}_{\text {sc }}$ data not shown). S-nitrosoglutathione-induced short-circuit current responses (peak $\mathrm{I}_{\mathrm{sc}}$ ), in the presence and absence of N20, were $39.1 \pm 1.6$ and $26.1 \pm 2.5 \mu \mathrm{A} / \mathrm{cm}^{2}$, respectively. These responses were found to be significantly different from each other (peak $\mathrm{I}_{\mathrm{sc}}$, $P<0.05, \mathrm{n}=3$, data not shown).

Next, we examined the response of N20 in the presence of L-NAME, a nitric oxide synthase inhibitor which inhibits the generation of endogenous nitric oxide. The application of L-NAME $1 \mathrm{mM}$ both sides caused a transient reduction in the basal short-circuit current (Figure 6A). The subsequent addition of $\mathrm{N} 2010 \mu \mathrm{g} / \mathrm{mL}$ apical increased the shortcircuit current by $9.4 \pm 1.2 \mu \mathrm{A} / \mathrm{cm}^{2}$. Finally, the addition of diphenylamine-2-carboxylate $1 \mathrm{mM}$ apical and $\mathrm{BaCl}_{2} 5 \mathrm{mM}$ basolateral reduced the short-circuit current by $6.6 \pm 0.4$ and $1.3 \pm 0.4 \mu \mathrm{A} / \mathrm{cm}^{2}$, respectively (Figure 6A). This increase in short-circuit current as a result of N20 was found not to be significantly different from the effects detected in the absence of L-NAME (control, $P>0.05$, unpaired $t$-test, $\mathrm{n}=3$ ). In controls, the short-circuit current was inhibited by the addition of diphenylamine-2-carboxylate $1 \mathrm{mM}$ apical $\left(5.4 \pm 0.2 \mu \mathrm{A} / \mathrm{cm}^{2}\right)$ and $\mathrm{BaCl}_{2} 5 \mathrm{mM}$ basolateral $\left(1.01 \pm 0.3 \mu \mathrm{A} / \mathrm{cm}^{2}\right.$, Figure $\left.6 \mathrm{~A}\right)$.

The effects of nitric oxide on short-circuit current in Calu-3 cells are known to be mediated by the activation of soluble guanylyl cyclase enzymes through increases in cGMP. ${ }^{20,25}$ To determine whether this pathway was involved in short-circuit current activation by N20, Calu-3 cells were pretreated with a selective inhibitor of soluble guanylyl cyclase, ODQ $10 \mu \mathrm{M}$ both sides. ODQ caused a transient reduction in short-circuit current and prevented the activation of the shortcircuit current by $\mathrm{N} 2010 \mu \mathrm{g} / \mathrm{mL}$ apical $(P<0.05$, unpaired $t$-test, $\mathrm{n}=3$, Figure 6B). As expected, the short-circuit current was inhibited by the addition of diphenylamine-2-carboxylate $1 \mathrm{mM}$ apical $\left(6.9 \pm 1.8 \mu \mathrm{A} / \mathrm{cm}^{2}\right)$ and $\mathrm{BaCl}_{2} 5 \mathrm{mM}$ basolateral (3.1 $\pm 0.5 \mu \mathrm{A} / \mathrm{cm}^{2}$, Figure $\left.6 \mathrm{~B}\right)$. These results indicate that soluble guanylyl cyclase and downstream cGMP signaling plays a crucial role in N20-mediated short-circuit current activation in Calu-3 cells.

\section{Excised inside-out patch clamp recordings of N20-stimulated CFTR activity}

Figure 7A shows that the addition of $\mathrm{N} 2050 \mu \mathrm{g} / \mathrm{mL}$ to the bath of the membrane patch activated CFTR $\mathrm{Cl}^{-}$channels with a $\mathrm{P}_{\mathrm{o}}$ value of $0.22 \pm 0.031(\mathrm{n}=3)$. The channel activity could be blocked by $500 \mu \mathrm{M} \mathrm{Au}(\mathrm{CN})_{2}^{-}$, ie, a blocker of the CFTR channel. Figure 7B shows the stimulation of CFTR channels by $20 \mathrm{nM}$ protein kinase $\mathrm{A}$ and $1 \mathrm{mM} \mathrm{MgATP}$. The subsequent addition of $\mathrm{N} 2050 \mu \mathrm{g} / \mathrm{mL}$ to the bath further increased the channel activity. In other studies, stimulation of the cAMP pathway by protein kinase $\mathrm{A} / \mathrm{MgATP}$ resulted in the activation of CFTR channels with $\mathrm{P}_{\mathrm{o}}=0.07 \pm 0.05$ $(\mathrm{n}=3)$. Subsequent addition of $\mathrm{N} 2050 \mu \mathrm{g} / \mathrm{mL}$ to the bath further increased CFTR activity to $P_{0}=0.34 \pm 0.09(P<0.05$, paired $t$-test, $\mathrm{n}=3)$. Control baby hamster kidney cell patches lacking expression of wild-type $\mathrm{CFTR} \mathrm{Cl}^{-}$channels showed no response when stimulated with $\mathrm{N} 2050 \mu \mathrm{g} / \mathrm{mL}$ (data not shown).

\section{Discussion}

We investigated a hypothesis that polystyrene nanoparticles have the ability to act as modulators of ion channel function in human airway epithelial cells. The main novel findings of this study were that acute exposure of epithelial cells to N20 led to the activation of transepithelial anion transport, an effect inhibited by diphenylamine-2-carboxylate, a CFTR $\mathrm{Cl}^{-}$channel blocker. The effectiveness of N20 to activate $\mathrm{CFTR}^{-}{ }^{-}$channels was comparable with that of the cAMP elevating agonist, forskolin. N20 activated cAMP-dependent basolateral $\mathrm{K}^{+}$channels and affected three distinct cell signaling systems concerned with ion channel activation in respiratory cells, ie, the cAMP, $\mathrm{Ca}^{2+}$, and soluble guanylyl 
A

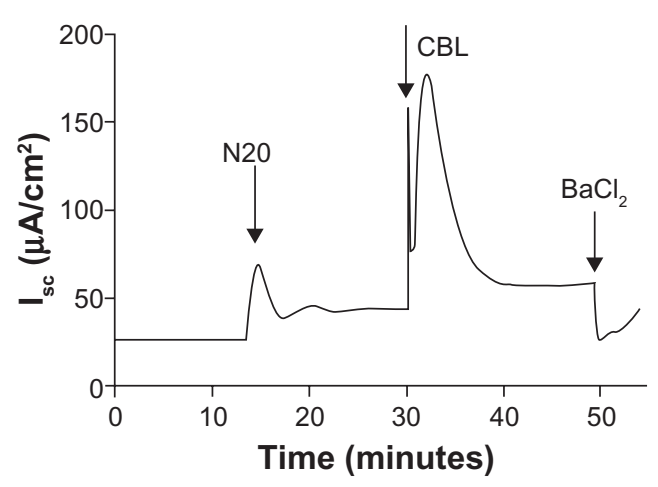

C

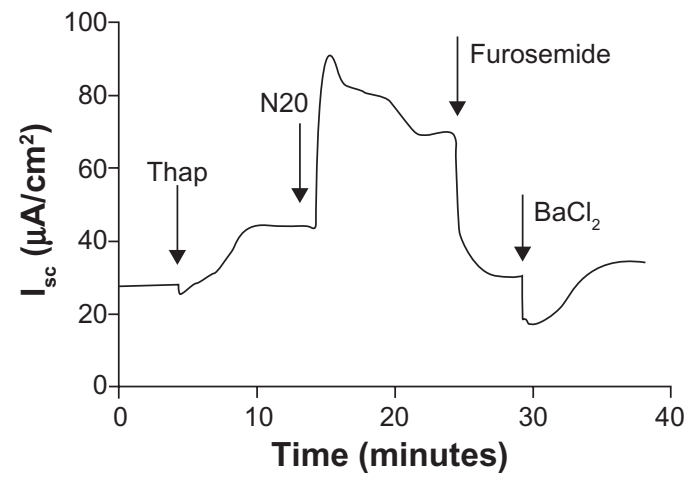

B

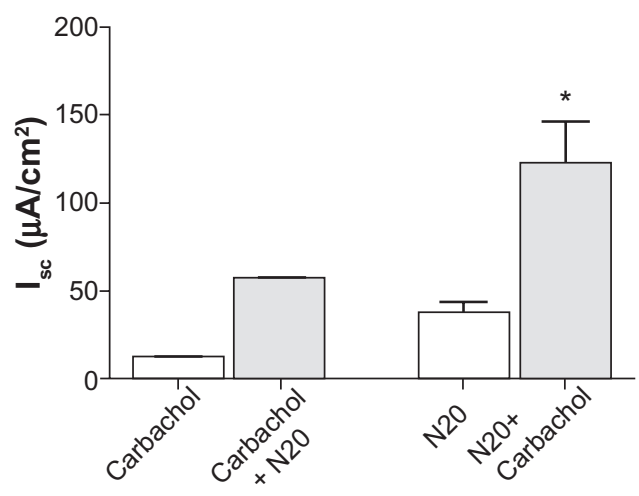

D

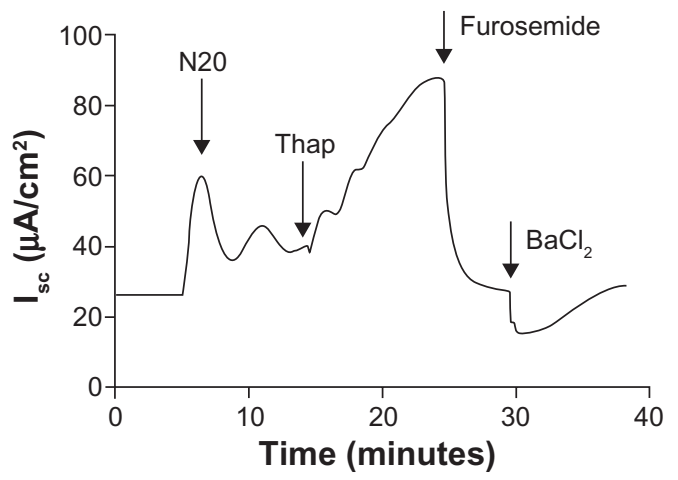

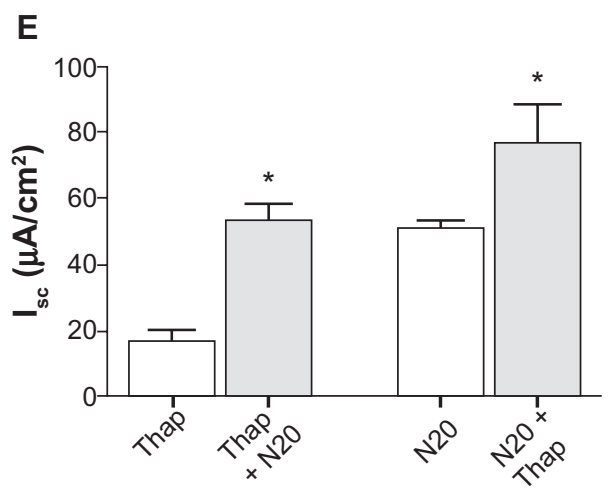

Figure 5 Effect of N20 on calcium-mediated anion secretion in Calu-3 cells. A) Carbachol-induced Isc (CBL) I00 $\mu$ M basolateral was significantly increased by prestimulation with $\mathrm{N} 2010 \mu \mathrm{g} / \mathrm{mL}$ apical, and $\mathrm{BaCl}_{2} 5 \mathrm{mM}$ basolateral as shown inhibited Isc. B) Statistical analysis of the effects of N20 on Isc in the presence and absence of carbachol. $* P<0.05$ ( $n=3$, one-way analysis of variance). C) Activation of Isc by thapsigargin (Thap) I $\mu$ M both sides in Calu-3 cells. N20 further increased Isc in thapsigargin pretreated cells. D) Thapsigargin-induced Isc was significantly increased by prestimulation with $\mathbf{N} 20$. Furosemide I $\mathrm{mM}$ basolateral and $\mathbf{B a C l}_{2}$, as shown in $\mathbf{C}$ and $\mathbf{D}$, inhibited Isc responses. E) Statistical analysis of the effects of N20 on Isc in the presence and absence of thapsigargin.

Note: $* P<0.05$ ( $n=3$, one-way analysis of variance).

cyclase-cGMP pathways. Our patch clamp studies also show the direct activation of single CFTR $\mathrm{Cl}^{-}$channels by N20.

We know that nanoparticle characteristics, including size, surface modification, and charge, are major factors influencing biological interactions with nanomaterials. Such characteristics can exert a profound effect on respiratory tissues, and thus be an important criterion for short-circuit current activation in Calu-3 cells. Nanoparticle surface modifications could influence the affinity of N20 to the plasma membrane. Wang et al examined the effects of polystyrene nanoparticles on single-component phospholipid bilayers using fluorescence and calorimetry experiments after mixing together either positively or negatively charged nanoparticles of approximately $20 \mathrm{~nm}$ in size in suspension with liposomes. ${ }^{26}$ 

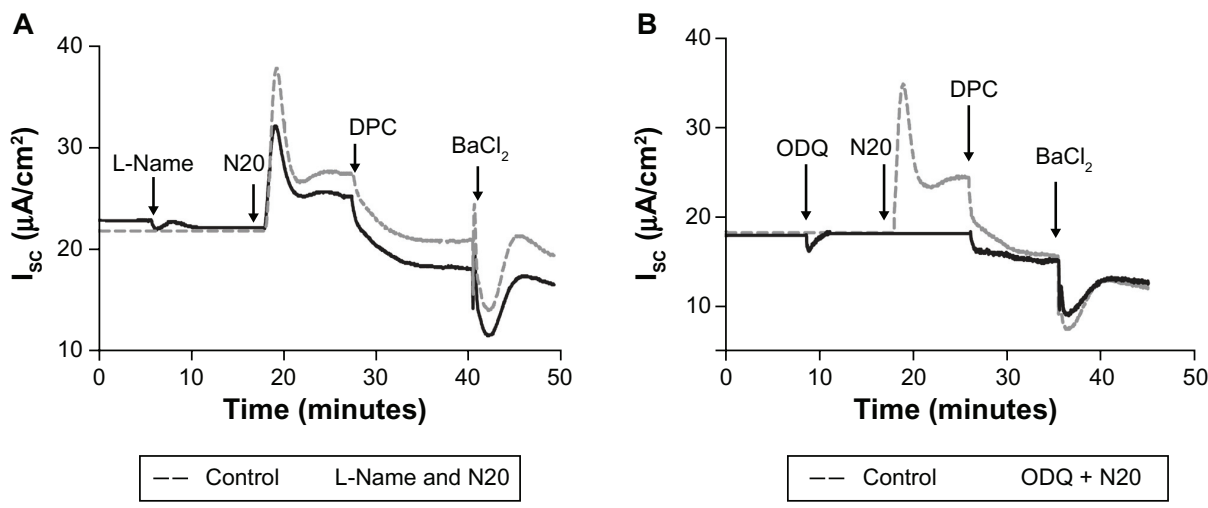

Figure 6 Effect of N20 on cGMP-mediated transepithelial anion secretion in Calu-3 cells. A) Prestimulation of cells with S-nitrosoglutathione I00 $\mu$ M both sides resulted in a significant decrease in N20-induced responses. $* P<0.05(n=3$, one-way analysis of variance). B) Pretreatment of cells with NG-nitro--arginine methyl ester I mM both sides did not inhibit the effects of $\mathrm{N} 2010 \mu \mathrm{g} / \mathrm{mL}$ apical on short-circuit current activation. C) Pretreatment of cells with IH-[I, 2, 4] oxadiazolol-[4, 3-a] quinoxalinI-one $10 \mu \mathrm{M}$ both sides inhibited the effects of $\mathrm{N} 20$ on short-circuit current. As shown in $\mathbf{B}$ ) and $\mathbf{C}$ ), short-circuit current was significantly reduced by the application of diphenylamine-2-carboxylate $1 \mathrm{mM}$ apical and $\mathrm{BaCl}_{2} 5 \mathrm{mM}$ basolateral.

The findings of their study showed that there was surface reconstruction where the nanoparticles absorbed onto the bilayer membrane, with negatively charged nanoparticles inducing local gelation in fluid bilayers and positively charged nanoparticles inducing gelled membranes to fluid locally. ${ }^{26}$ In 2010, Yang and Ning investigated the interactions between charged nanoparticles (positive, negative, and uncharged) and charge-neutral phospholipid membranes by coarse-grained molecular dynamic simulations. ${ }^{27}$ Their results were discussed in terms of free energy, entropy, and enthalpy, where they describe an energy barrier existing between lipids and charged nanoparticles. They concluded that electrostatic attractions help to improve the adhesion of charged nanoparticles to phospholipid membranes, and that increases in electrostatic energy can result in charged nanoparticles being almost fully wrapped by membrane. ${ }^{27}$ Chen et al showed using whole cell patches that cationic nanoparticles working at noncytotoxic concentrations can cause nanoscale defects in the plasma membrane of human embryonic kidney and human epidermoid carcinoma cells. ${ }^{28}$ Thus, membrane fluidity may be affected by nanoparticle charge.

Polystyrene nanoparticles have been shown specifically to affect processes and membrane structure dynamics on airway epithelial cells. Salomon and Ehrhardt showed that small carboxylated and sulfated polystyrene nanoparticles reduced P glycoprotein-mediated effluxes of Rh123 from alveolar airway cells, A549. ${ }^{18}$ They hypothesized that this effect was due to the direct interaction and interference of polystyrene nanoparticles with $\mathrm{P}$ glycoprotein function. Brandenberger et $\mathrm{al}^{29}$ exposed human pulmonary epithelial cells to fluorescent polystyrene nanospheres $(41 \mathrm{~nm})$ without surface charge modifications. They found that these particles induced changes in the apical plasma membrane surface area as measured by design-based stereology. They concluded that this observed enlargement was dependent on particle surface area dose. ${ }^{29}$ Interestingly, our own data show that short-circuit current activation by N20, working at noncytotoxic concentrations, occurs in a concentrationdependent manner in Calu-3 cells. Therefore, nanoparticlemembrane interactions with subsequent secondary activation
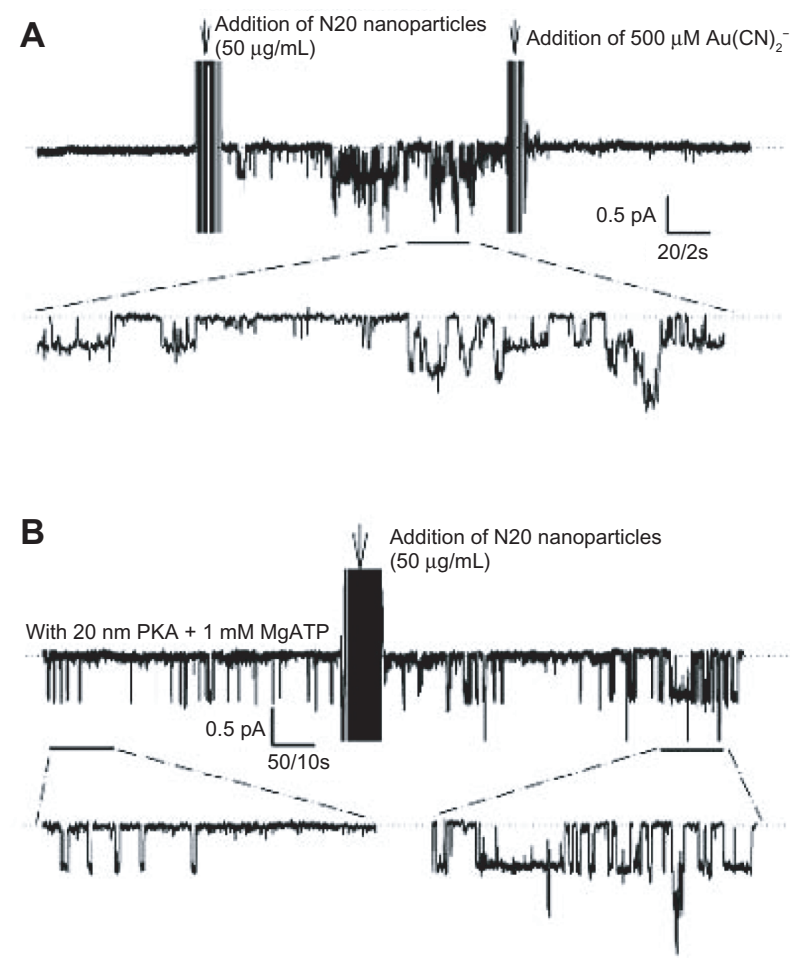

Figure 7 Patch clamp studies of the effects of $\mathrm{N} 20$ on single CFTR $\mathrm{Cl}^{-}$channel function. A) Silent CFTR Cl- channels were activated by $\mathrm{N} 2050 \mu \mathrm{g} / \mathrm{mL}$ and blocked by $\mathrm{Au}(\mathrm{CN})_{2}^{-} 500 \mu \mathrm{M}$ in excised, inside-out patches. B) Stimulation by N20 of CFTR $\mathrm{Cl}^{-}$channels preactivated with protein kinase A $20 \mathrm{nM}$ and MgATP I mM in excised inside-out patches $(n=3$, dashed lines indicate closed CFTR state). 
of cell signaling pathways may play an important role in our observed effects.

We found that the effects of N20 on CFTR-driven shortcircuit current responses in Calu-3 cells were abolished by ODQ, a selective inhibitor of soluble guanylyl cyclase, ${ }^{30}$ implicating the soluble guanylyl cyclase-cGMP pathway and cGMP-dependent phosphorylation of $\mathrm{CFTR}^{-}$channels in the actions of N20. Pretreatment of epithelial cells with an inhibitor of nitric oxide synthase, ie, L-NAME, did not modify the activator effects of N20. Because nitric oxide synthase is present and active in Calu-3 cells regulating anion secretion, ${ }^{20}$ these data together indicate that soluble guanylyl cyclase, but not nitric oxide synthase-dependent responses, are targeted by N20. Our experiments using agonists of adenylate (forskolin) and guanylyl (S-nitrosoglutathione) cyclase showed that prestimulation of either system largely abolishes the effects of the nanoparticles. Similarly, the inhibition of soluble guanylyl cyclase by ODQ abolished nanoparticle-driven short-circuit current responses.

There are a number of levels where the cAMP and cGMP systems can cross-talk with each other. This includes activation of respective protein kinases (A and $G$ ) involved in channel gating, as well as cGMP-mediated inhibition of cAMP breakdown by the family of phosphodiesterases. ${ }^{31}$ In turn, nanoparticle-stimulated increases in cyclic nucleotide levels will increase protein kinase-controlled protein phosphorylation and the subsequent phosphorylation of sites on the regulatory domain of $\mathrm{CFTR}^{-}$channels, which in turn will facilitate the exit of $\mathrm{Cl}^{-}$through apically located CFTR $\mathrm{Cl}^{-}$channels, an effect supported by an increased bioavailability of $\mathrm{Ca}^{2+} \cdot 20,32$

Other groups have also found that nanomaterials can affect $\mathrm{Ca}^{2+}$ and cAMP-signaling systems in neuronal and fibroblast cell models. Tang et al showed that nanoparticles can affect intracellular $\mathrm{Ca}^{2+}$ levels in mammalian cells. ${ }^{33}$ They demonstrated that unmodified cadmium selenium quantum dots elevate cytoplasmic calcium levels in primary cultures of rat hippocampal neurons. The mechanism for this activation is still unknown, although the group did identify that the increase in cytoplasmic calcium involved both extracellular $\mathrm{Ca}^{2+}$ influx and internal $\mathrm{Ca}^{2+}$ release. Also, extracellular influx of $\mathrm{Ca}^{2+}$ could only be partially inhibited by a $\mathrm{Ca}^{2+}$ channel antagonist (eg, verapamil), whereas internal $\mathrm{Ca}^{2+}$ release was abolished by treatment of cells with clonazepam, a specific inhibitor of mitochondrial $\mathrm{Na}^{+}-\mathrm{K}^{+}$exchangers, and with antrolene, an antagonist of ryanodine receptors in the endoplasmic reticulum. ${ }^{33}$
Many research groups are interested in the manipulation of magnetic nanoparticles, such as magnetic tweezers or ligand-coated magnetic nanoparticles which are capable of mechanical activation of cell receptors. ${ }^{34}$ Magnetic particles used to investigate mechanotransduction, such as integrinbound collagen-coated ferric oxide beads, have revealed that tension applied on human fibroblasts can cause $\mathrm{Ca}^{2+}$ spikes which can modulate cellular functions. ${ }^{35}$ Meyer et al, using suspended bovine endothelial cells and a magnetic twisting device demonstrated that, when a controlled twisting (shear) stress of 15.6 dyne per $\mathrm{cm}^{-2}$ was applied to ligand-coated magnetic microbeads in contact with these cells, cAMP production was increased due to adenylyl cyclase activation. ${ }^{36}$ Thus, the literature shows that mechanical stress applied to the cell surface can alter both $\mathrm{Ca}^{2+}$ and cAMP signaling.

N20 had distinct targets other than CFTR $\mathrm{Cl}^{-}$channels. $\mathrm{K}^{+}$ions are recycled across the basolateral membrane by $\mathrm{K}^{+}$channels which work to maintain the negative potential difference of the cell interior. The opening of basolateral $\mathrm{K}^{+}$ channels in epithelial cells is an important process for anion secretion because it causes the cell to become hyperpolarized which, in turn, increases the electrical gradient for $\mathrm{Cl}^{-}$ions to exit across the apical surface of the epithelium. ${ }^{37}$ Our studies show that N20 can also activate cAMP-dependent basolateral $\mathrm{K}^{+}$channels. The evidence for this comes from experiments which show that $\mathrm{N} 20$-activated $\mathrm{K}^{+}$currents were inhibited by XE991, an inhibitor of cAMP-sensitive basolateral $\mathrm{K}^{+}$channels, and that the effects of $\mathrm{N} 20$ on basolateral $\mathrm{K}^{+}$currents were abolished by pretreating cells with forskolin. It is likely that stimulation of cAMP, along with significant cross-talk between membrane systems, ${ }^{38}$ can lead to indirect activation of cAMP-regulated $\mathrm{K}^{+}$channels upon apical exposure of Calu-3 cells to N20.

The NKCC1 cotransporter isoform is expressed on the basolateral membrane of secretory epithelia, where it acts in concert with other transporters and ion channels, such as CFTR, basolateral $\mathrm{K}^{+}$channels, and $\mathrm{Na}^{+}-\mathrm{K}^{+}$pumps, to produce transepithelial $\mathrm{Cl}^{-}$secretion. NKCC is expressed on virtually all mammalian cells, where it functions to maintain cell volume. ${ }^{39}$ The observed effects of $\mathrm{N} 20$ on $\mathrm{Cl}^{-}$and $\mathrm{HCO}_{3}^{-}$transport are most likely indirect consequences of short-circuit current activation, eg, the NKCC cotransporter is activated to restore intracellular chloride levels due to the efflux of $\mathrm{Cl}^{-}$from cells by activated CFTR $\mathrm{Cl}^{-}$channels and, in turn, $\mathrm{HCO}_{3}{ }^{-}$transport is more likely linked to the activation of basolateral $\mathrm{K}^{+}$channels. ${ }^{37}$ Finally, the cyclic forskolin response observed after stimulation of cells with N20 (Figure 2A) could be the result of $\mathrm{Cl}^{-}$bursts out of the cell 
due to the unsynchronized effects of NKCC cotransporters and $\mathrm{CFTR}^{-}{ }^{-}$channels working to restore depleted intracellular chloride levels.

We used the inside-out configuration of the patch clamp technique because it allowed us to study the interaction of nanoparticles with the intracellular domains of CFTR $\mathrm{Cl}^{-}$channels. No other research group to our knowledge has investigated the effect of nanoparticles on ion channel function using this configuration of the technique. In 2009, Zhao et al showed using the whole cell patch clamp technique that zinc nanoparticles enhanced the current amplitudes of sodium and potassium by a mechanism mainly relying on increasing the opening number of sodium channels and delaying rectifier potassium channels..$^{40}$ Overall, that study showed that zinc nanoparticles have the ability to affect ionic homeostasis and physiological processes in rat hippocampal CA3 pyramidal neurons. We have shown in baby hamster kidney cells that $\mathrm{N} 20$ can directly activate CFTR $\mathrm{Cl}^{-}$channels both in the presence and absence of ATP and protein kinase A. Studies using nucleotide binding domain mutants of $\mathrm{CFTR}^{-} \mathrm{Cl}^{-}$channels, such as G551D and G1349D, demonstrate that most CFTR activators have decreased affinity for activating mutant CFTR $\mathrm{Cl}^{-}$channels. ${ }^{41}$ Therefore, putative binding sites on the nucleotide-binding domains of CFTR $\mathrm{Cl}^{-}$channels are proposed to be target(s) for many CFTR activators. ${ }^{42,43}$ However, our data indicate that the primary mechanism of single $\mathrm{CFTR}^{-}{ }^{-}$channel activation by N20 may not involve the nucleotide-binding domains or regulatory domain of CFTR, because these sites have been previously stimulated by ATP and protein kinase A. Therefore, we cannot rule out the possibility that $\mathrm{N} 20$ may in some way influence structural changes in the transmembrane domains of CFTR $\mathrm{Cl}^{-}$channels, resulting in channel activation.

Altogether, our data demonstrate that polystyrene nanoparticles can affect processes at the plasma membrane on airway epithelial cells specifically with regard to ion channel function and ionic homeostasis. Furthermore, once inside airway cells, our patch clamp data demonstrate that polystyrene nanoparticles could potentially affect $\mathrm{CFTR} \mathrm{Cl}^{-}$channel function directly. This is an exciting observation because it gives us an insight as to how nanoparticles might behave once inside the cell. More experimental data is needed to clarify the precise sequence of molecular events following the exposure of epithelial cells to nanoparticles and also the interesting data that reveal the selectivity for the stimulation of cAMP-regulated $\mathrm{K}^{+}$channels in comparison with $\mathrm{Ca}^{2+}$-regulated ones on the basolateral membrane. Finally, experimental validation with regard to other nanoparticle types, eg, silica, titanium, and zinc, would have to be done in future studies to establish if NP composition is an important factor underlying the ability of polystyrene nanoparticles to activate $\mathrm{CFTR} \mathrm{Cl}^{-}$channels and affect ion transport in airway epithelial cells.

\section{Conclusion}

Our studies demonstrate that polystyrene nanoparticles cannot be considered as a simple neutral vehicle for drug delivery. Polystyrene nanoparticles in the respiratory system may influence cell signaling systems (cyclic nucleotide and calcium) as a result of nanoparticle-membrane interactions. Finally, after endocytosis by epithelial cells lining the airways, polystyrene nanoparticles have the potential to interact directly with ion channels such as CFTR.

\section{Acknowledgments}

This work was supported by a Strategic Research Cluster grant from Science Foundation Ireland, as well as support from FÁS Science Challenge Ireland and the Canadian Cystic Fibrosis Foundation.

\section{Disclosure}

The authors report no conflicts of interest in this work.

\section{References}

1. Riordan JR, Rommens JM, Kerem B, et al. Identification of the cystic fibrosis gene: Cloning and characterisation of complementary DNA. Science. 1989;245:1066-1073.

2. Collins FS. Cystic fibrosis: Molecular biology and therapeutic implications. Science. 1992;256:774-779.

3. Gadsby DC, Vergani P, Csanády L. The ABC protein turned chloride channel whose failure causes cystic fibrosis. Nature. 2006;440: 477-483.

4. Ostedgaard LS, Baldursson O, Welsh MJ. Regulation of the cystic fibrosis transmembrane conductance regulator $\mathrm{Cl}^{-}$channel by its $\mathrm{R}$ domain. J Biol Chem. 2001;276:7689-7692.

5. Vergani P, Lockless SW, Nairn AC, et al. CFTR channel opening by ATP-driven tight dimerization of its nucleotide-binding domains. Nature. 2005;433:876-880.

6. US Cystic Fibrosis Foundation. Available at: http://www.genet.sickkids on.ca/cftr. Accessed April 8, 2011.

7. Livraghi A, Randell SH. Cystic fibrosis and other respiratory diseases of impaired mucus clearance. Toxicol Pathol. 2007;35:116-129.

8. Salinas D, Haggie PM, Thiagarajah JR, et al. Submucosal gland dysfunction as a primary defect in cystic fibrosis. FASEB J. 2004;19: 431-433.

9. McAuley DF, Elborn JS. Cystic fibrosis: Basic science. Paediatr Respir Rev. 2000;1:93-100

10. Azarmi S, Roa WH, Löbenberg R. Targeted delivery of nanoparticles for the treatment of lung diseases. Adv Drug Deliv Rev. 2008;60: 863-875.

11. Yacobi NR, Phuleria HC, Demaio L, et al. Nanoparticle effects on rat alveolar epithelial cell monolayer barrier properties. Toxicol In Vitro. 2007;21:1373-1381.

12. Liu Z, Ren G, Zhang T, et al. Action potential changes associated with the inhibitory effects on voltage-gated sodium current of hippocampal CA1 neurons by silver nanoparticles. Toxicology. 2009;264:179-184. 
13. Jiang W, Kim BY, Rutka JT, et al. Nanoparticle-mediated cellular response is size-dependent. Nat Nanotechnol. 2008;3:145-150.

14. Shi Y, Wang F, He J, et al. Titanium dioxide nanoparticles cause apoptosis in BEAS-2B cells through the caspase 8/t-Bid-independent mitochondrial pathway. Toxicol Lett. 2010;196:21-27.

15. Borisov SM, Mayr T, Mistlberger G, et al. Precipitation as a simple and versatile method for preparation of optical nanochemosensors. Talanta. 2009;79:1322-1330.

16. Tsapis N, Bennett D, Jackson B, et al. Trojan particles: Large porous carriers of nanoparticles for drug delivery. Proc Natl Acad Sci U S A. 2002;99:12001-12005.

17. Lundqvist M, Stigler J, Elia I, et al. Nanoparticle size and surface properties determine the protein corona with possible implications for biological impacts. Proc Natl Acad Sci U S A. 2008;105:14265-14270.

18. Salomon JJ, Ehrhardt C. Nanoparticles attenuate P-glycoprotein/ MDR1 function in A549 human alveolar epithelial cells. Eur J Pharm Biopharm. 2011;77:392-397.

19. Duta V, Duta F, Puttagunta L, et al. Regulation of basolateral $\mathrm{Cl}^{-}$channels in airway epithelial cells: The role of nitric oxide. J Membr Biol. 2006;213:165-174.

20. Duszyk M. Regulation of anion secretion by nitric oxide in human airway epithelial cells. Am J Physiol Lung Cell Mol Physiol. 2001;281: L450-L457.

21. Linsdell $\mathrm{P}$, Gong X. Multiple inhibitory effects of $\mathrm{Au}(\mathrm{CN})_{2}^{-}$ions on cystic fibrosis transmembrane conductance regulator $\mathrm{Cl}^{-}$channel currents. J Physiol. 2002;540:29-38.

22. McCarty NA, McDonough S, Cohen BN, et al. Voltage-dependent block of the cystic fibrosis transmembrane conductance regulator $\mathrm{Cl}^{-}$channel by two closely related arylaminobenzoates. J Gen Physiol. 1993; 102:1-23.

23. MacVinish LJ, Guo Y, Dixon AK, et al. Xe991 reveals differences in $\mathrm{K}(+)$ channels regulating chloride secretion in murine airway and colonic epithelium. Mol Pharmacol. 2001;60:753-760.

24. Watkins DN, Peroni DJ, Basclain KA, et al. Expression and activity of nitric oxide synthases in human airway epithelium. Am J Respir Cell Mol Biol. 1997;16:629-639.

25. Vaandrager A, Smolenski A, Tilly BC, et al. Membrane targeting of cGMP-dependent protein kinase is required for cystic fibrosis transmembrane conductance regulator $\mathrm{Cl}^{-}$channel activation. Proc Natl Acad Sci U S A. 1998;95:1466-1471.

26. Wang B, Zhang L, Bae SC, et al. Nanoparticle-induced surface reconstruction of phospholipid membranes. Proc Natl Acad Sci US A. 2008; 105:18171-18175.

27. Yang Li, Ning Gu. Thermodynamics of charged nanoparticle adsorption on charge-neutral membranes: a simulation study. J Phys Chem B. 2010;114:2749-2754

28. Chen J, Hessler JA, Putchakayala K, et al. Cationic nanoparticles induce nanoscale disruption in living cell plasma membrane. J Phys Chem B. 2009;113:11179-11185.
29. Brandenberger C, Rothen-Rutishauser B, Blank F, et al. Particles induce apical plasma membrane enlargement in epithelial lung cell line depending on particle surface area dose. Respir Res. 2009;10:22.

30. Moro MA, Russel RJ, Cellek S, et al. cGMP mediates the vascular and platelet actions of nitric oxide: Confirmation using an inhibitor of the soluble guanylyl cyclase. Proc Natl Acad Sci U S A. 1996;93: 1480-1485

31. Zaccolo M, Movsesian MA. cAMP and cGMP signalling cross-talk: Role of phosphodiesterases and implications for cardiac pathophysiology. Circ Res. 2007;100:1569-1578.

32. Namkung W, Finkbeiner WE, Verkman AS. CFTR-adenylyl cyclase I association responsible for UTP activation of CFTR in welldifferentiated primary human bronchial cell cultures. Mol Biol Cell. 2010;21:2639-2648.

33. Tang M, Xing T, Zeng J, et al. Unmodified CdSe quantum dots induce elevation of cytoplasmic calcium levels and impairment of functional properties of sodium channels in rat primary cultured hippocampal neurons. Environ Health Perspect. 2008;116:915-922.

34. Sniadecki NJ. Minireview: A tiny touch: Activation of cell signalling pathways with magnetic nanoparticles. Endocrinology. 2010;151: $451-457$.

35. Glogauer M, Ferrier J, McCulloch CA. Magnetic fields applied to collagen-coated ferric oxide beads induce stretch-activated $\mathrm{Ca}^{2+}$ flux in fibroblasts. Am J Physiol Cell Physiol. 1995;269:C1093-C1104.

36. Meyer CJ, Alenghat FJ, Rim P, et al. Mechanical control of cyclic AMP signalling and gene transcription through integrins. Nat Cell Biol. 2000; 2:666-668.

37. Cowley EA, Linsdell P. Characterization of basolateral $\mathrm{K}^{+}$channels underlying anion secretion in the human airway cell line Calu-3. J Physiol. 2002;538:747-757.

38. Driessche WV, Kreindler JL, Malik AB, et al. Interrelations/cross talk between transcellular transport function and paracellular tight junctional properties in lung epithelial and endothelial barriers. Am J Physiol Lung Cell Mol Physiol. 2007;293:L520-L524.

39. Matthews JB. Molecular regulation of $\mathrm{Na}^{+}-\mathrm{K}^{+}-2 \mathrm{Cl}^{-}$cotransporter (NKCC1) and epithelial chloride secretion. World J Surg. 2002;26: 826-830.

40. Zhao J, Xu L, Zhang T, et al. Influences of nanoparticle zinc oxide on acutely isolated rat hippocampal CA3 pyramidal neurons. Neurotoxicology. 2009;30:220-230.

41. Moran O, Galietta LJ, Zegarra-Moran O. Binding site of activators of the cystic fibrosis transmembrane conductance regulator in the nucleotide binding domains. Cell Mol Life Sci. 2005;62:446-460.

42. Cai Z, Sheppard DN. Phloxine B interacts with the cystic fibrosis transmembrane conductance regulator at multiple sites to modulate channel activity. J Biol Chem. 2002;277:19546-19553.

43. Ai T, Bompadre SG, Wang X, et al. Capsaicin potentiates wild-type and mutant cystic fibrosis transmembrane conductance regulator chloridechannel currents. Mol Pharmacol. 2004;65:1415-1426.
International Journal of Nanomedicine

\section{Publish your work in this journal}

The International Journal of Nanomedicine is an international, peerreviewed journal focusing on the application of nanotechnology in diagnostics, therapeutics, and drug delivery systems throughout the biomedical field. This journal is indexed on PubMed Central, MedLine, CAS, SciSearch ${ }^{\circledR}$, Current Contents ${ }^{\circledR} /$ Clinical Medicine,

\section{Dovepress}

Journal Citation Reports/Science Edition, EMBase, Scopus and the Elsevier Bibliographic databases. The manuscript management system is completely online and includes a very quick and fair peer-review system, which is all easy to use. Visit http://www.dovepress.com/ testimonials.php to read real quotes from published authors. 